\title{
Compliance with a COPD bundle of care in an Australian emergency department: a cohort study
}

\section{Alexis Gerber MBBS}

Registrar, Department of Emergency Medicine, Western Health, St Albans, Victoria, Australia

\section{Catriona Moynihan MBBS}

Registrar, Department of Emergency Medicine, Western Health, St Albans, Victoria, Australia

\section{Sharon Klim BN}

Research manager, Joseph Epstein Centre for Emergency Medicine Research, St

Albans, Victoria, Australia

\section{Peter Ritchie MBBS MPubHIth FACEM}

Emergency physician, Department of Emergency Medicine, Western Health, St Albans, Victoria, Australia

\section{Anne-Maree Kelly MD FACEM}

Director, Joseph Epstein Centre for Emergency Medicine Research, St Albans, Victoria, Australia and Professorial Fellow, School of Medicine -Western Clinical School, The University of Melbourne, Parkville, Victoria, Australia

\section{Word counts:}

Abstract: 244 Text: 1976 References: $16 \quad$ Tables: 2 Figures: 0

Running head: COPD bundle of care in ED

\section{Conflict of interest:}

The authors have no conflicts of interest to report.

\section{Address for correspondence:}

Prof AM Kelly, JECEMR, Sunshine Hospital, St Albans 3021 VIC Australia

Email: anne-maree.kelly@wh.org.au

This is the author manuscript accepted for publication and has undergone full peer review but has not been through the copyediting, typesetting, pagination and proofreading process, which may lead to differences between this version and the Version record. Please cite this article as doi:10.1111/ crj.12583. 


\section{Compliance with a COPD bundle of care in an Australian emergency department: a cohort study}

Alexis Gerber MBBS

Registrar, Department of Emergency Medicine, Western Health, St Albans, Victoria, Australia

Catriona Moynihan MBBS

Registrar, Department of Emergency Medicine, Western Health, St Albans, Victoria, Australia

\section{Sharon Klim BN}

Research manager, Joseph Epstein Centre for Emergency Medicine Research, St

Albans, Victoria, Australia

\section{Peter Ritchie MBBS MPubHIth FACEM}

Emergency physician, Department of Emergency Medicine, Western Health, St Albans, Victoria, Australia

\section{Anne-Maree Kelly MD FACEM}

Director, Joseph Epstein Centre for Emergency Medicine Research, St Albans, Victoria, Australia and Professorial Fellow, School of Medicine -Western Clinical School, The University of Melbourne, Parkville, Victoria, Australia

\section{Word counts:}

Abstract: 244 Text: $1543 \quad$ References: $18 \quad$ Tables: 2 Figures: 0

Running head: COPD bundle of care in ED

\section{Conflict of interest:}

The authors have no conflicts of interest to report.

Address for correspondence:

Prof AM Kelly, JECEMR, Sunshine Hospital, St Albans 3021 VIC Australia Email: anne-maree.kelly@wh.org.au 


\section{ABSTRACT}

Introduction: Bundles of care are gaining popularity for treating acute severe illness.

Objective: To describe compliance with bundle of care elements (individually and as a 'bundle') for patients treated for chronic obstructive pulmonary disease (COPD) exacerbations in the emergency department (ED).

Methods: Retrospective observational study of patients presenting in the 2014 calendar year with an ED diagnosis of COPD. The primary outcomes of interest were compliance with key bundle of care elements (individually and as a 'bundle'). Analysis is descriptive. Results: 381 patients were studied. Median age was 71 (IQR 64-80), 59\% were male and 77\% arrived by ambulance. Median duration of symptoms was 3 days (IQR 2-6 days). Compliance with the bundle elements was $90 \%$ for administration of controlled oxygen therapy (if oxygen given), $87 \%$ for administration of inhaled bronchodilators, $79 \%$ for administration of systemic corticosteroids, $75 \%$ of administration of antibiotics if evidence of infection, $77 \%$ for taking of a blood gas in non-mild disease, $98 \%$ for taking of a chest xray and $74 \%$ for administration of NIV if $\mathrm{pH}<7.3$. Compliance with all appropriate elements of the defined bundle of care was $49 \%$. There was no difference in mean length of stay for admitted patients $(p=0.44)$, in-hospital mortality $(p=1.00)$ or re-admission within 30 days $(p=0.72)$ by bundle compliance Conclusion: Compliance with individual assessment and treatment recommendations was generally high, however compliance with the overall recommended bundle was only $49 \%$. This indicates that there is an opportunity to improve care in these patients.

Key words: COPD, exacerbation, bundle of care, quality 


\section{INTRODUCTION}

Exacerbations of chronic obstructive pulmonary disease (COPD) are common presentations to emergency departments (ED). Recent Australian guidelines [1] stress the importance of a number of assessments and treatments in the acute phase of care in order to optimize outcomes. These include the use of controlled oxygen therapy, inhaled bronchodilators, corticosteroids, antibiotics if there is clinical, laboratory or chest xray (CXR) evidence of infection, the taking of a chest xray, blood gas analysis for cases classified as more than mild and non-invasive ventilation (NIV) in patients with significant respiratory acidosis. There is limited data regarding compliance with each of these elements in Australasian ED.

In addition, there is growing evidence that a bundle of care approach increases compliance with guidelines and may improve outcomes. A bundle of care is a small set of evidence-based practices that when performed collectively and reliably improve patient outcomes.[2] Examples include central line bundles, ventilator bundles and sepsis bundles.[2,3]

The objectives of this study were to describe compliance with key bundle of care elements (individually and as a 'bundle') for patients treated for COPD exacerbations in the ED.

\section{METHODS}

This was a retrospective observational study performed by medical record review. It was conducted in the EDs of two metropolitan teaching hospitals in Melbourne, Australia. The EDs have a combined annual census of approximately 100,000 patients.

Patients were eligible for inclusion if they presented in the calendar year 2014 and were adult (age $>40$ years) with an ED discharge diagnosis coded as COPD exacerbation. Age over 40 was arbitrarily chosen in order to screen out patients more likely to have other conditions such 
as asthma. Patients were excluded if the medical record was missing, they left without medical treatment, were not an ED presentation or the case was miscoded (it was clearly not COPD).

Data was collected onto a piloted data collection form. Data collected included demographics, co-morbidities, chronic medications, clinical and investigation features, treatment in ED, ED disposition and outcome. Data collectors were trained to collect the required data and provided with a data dictionary but not blinded to the objectives of the study. The data collection form is available at online appendix $A$. It should be noted that during the study period the EDs did not have proformas or checklists to guide management of COPD. Delivery of controlled oxygen therapy was defined as provision of oxygen therapy if required by use of nasal prongs, a venturi-type system or NIV in severe cases. Disease severity describes the severity of this exacerbation and was classified as described by the treating clinician in the medical record; it was a subjective assessment based on all available clinical and investigation data. It should be noted that the ED does not have access to acute spirometry for confirmation of diagnosis and classification of severity. Oxygen saturation was recorded as the first measurement in the ED, recognizing that a significant proportion of patients arriving by ambulance were already receiving oxygen therapy at ED arrival. $\mathrm{pH}$ has been reported as either arterial or venous $\mathrm{pH}$ which have been found to have close agreement.[4] The participating EDs routinely use venous blood gas parameters to guide initial care so we are unable to report arterial $\mathrm{pCO}_{2}$ distribution.

The primary outcomes of interest were compliance with key bundle of care elements (individually and as 'bundles') for patients treated for COPD exacerbations in the ED. For bundle elements inhaled bronchodilators and systemic corticosteroids, these were regarded as complied with if administered either in ED or the pre-hospital setting (by ambulance paramedics). Antibiotics were considered given if received in ED or taking current course at ED arrival. Secondary outcomes of interest were comparison of mortality, length of stay (LOS) and 
re-admission within 30 days between groups with and without bundle of care compliance. For this study, the bundle of care was defined as controlled oxygen therapy after initial assessment (if oxygen administered), administration of inhaled bronchodilators, systemic corticosteroids and antibiotics (if there is clinical, laboratory or CXR evidence of infection), the taking of a chest xray, blood gas analysis for cases classified as more than mild and non-invasive ventilation in patients with $\mathrm{pH}<7.3$. These reflect the key recommendations of the COPD-X plan.[1]

Inter-rater reliability of data collection was assessed for 40 patients for the items age, gender, past history of heart failure (HF), smoking status, use of venturi system to administer oxygen, administration of non-invasive ventilation (NIV), administration of intravenous (IV) corticosteroids, antibiotics and inhaled beta sympathomimetic agents. Agreement was 100\% for gender, use of venturi system for oxygen delivery, use of NIV and administration of IV corticosteroids (kappa 1.00). It was $98 \%$ for administration of antibiotics and inhaled beta sympathomimetic agents (kappa 0.95). It was $95 \%$ for age (kappa 0.90 ) and $93 \%$ for past history of HF (kappa 0.90) and smoking status (kappa 0.85).

Analysis was by descriptive statistics - percent with $95 \%$ confidence intervals $(\mathrm{Cl})$ and mean with standard deviation (SD) for those following a normal distribution and median and interquartile range (IQR) as appropriate. For the comparisons of mortality and LOS, Chi Square or Fishers Exact Test, t-test and Mann-Whitney $U$ test were used using Analyse-It ${ }^{\mathrm{TM}}$ software. Regarding sample size, the study was powered to detect a difference in LOS between bundle compliance groups ( 8 days vs. 6 days, standard deviation 6 days, $p<0.05$, two-sided test). This would require approximately 300 admitted cases. The rationale for chosing these LOS were the data that mean LOS is a multi-country comparison was approximately 8 days [5] and that a two day reduction in LOS is clinically meaningful for both patients and the health system. As the admission rate of COPD is approximately $75 \%$ (local data), we aimed to collect data from at 
least 360 eligible cases. These were chosen as the first 30 cases coded as COPD in each month and an additional 25 random cases to allow for exclusions as described above. While cases were not consecutive, we believe that this approach is unlikely to have introduced any systematic bias. The project was approved as a quality assurance project by the Western Health Low Risk Ethics Panel. Patient consent for data collection was not required.

\section{RESULTS}

381 patients met inclusion criteria. Median age was 71 (SD 12), $60 \%$ were male and $77 \%$ arrived by ambulance. Home oxygen therapy was used by $19 \%$. Median duration of symptoms was 3 days (IQR 2-6 days). Exacerbations were classified as mild in $31 \%$ of cases, moderate in $55 \%$ and severe in $14 \%$. Characteristics of the sample are summarized in table 1.

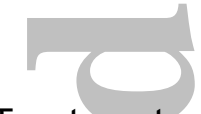

Treatment administered and outcomes are summarized in Table 2. All patients with initial oxygen saturation below $88 \%$ received oxygen therapy; $97 \%$ as controlled oxygen therapy. In the remaining cases the mode of oxygen delivery was unclear. Compliance with the bundle elements was $90 \%$ for administration of controlled oxygen therapy (if oxygen given), $87 \%$ for administration of inhaled bronchodilators, $79 \%$ for administration of systemic corticosteroids, $75 \%$ of administration of antibiotics if evidence of infection, $77 \%$ for taking of a blood gas in nonmild disease, $98 \%$ for taking of a chest xray and $74 \%$ for administration of NIV if $\mathrm{pH}<7.3$. Compliance with all appropriate elements of the defined bundle of care was $49 \%$. Compliance with the bundle of care varied with disease severity. Eighty three percent of exacerbations classified as severe received all indicated bundle elements compared with $47 \%$ of exacerbations classified as moderate and $38 \%$ of exacerbations classified as mild. (Omnibus Chi Square; $p<0.0001)$ 
There was no difference in mean LOS for admitted patients (t-test, $p=0.44$ ), in-hospital mortality (Fishers test, $p=1.00$ ) or re-admission within 30 days (Chi Square, $p=0.72$ ) by bundle compliance

\section{DISCUSSION}

Our data shows that while compliance with individual assessment and treatment recommendations is generally high, compliance with the overall recommended bundle is only $49 \%$. No difference in LOS, re-admission within 30 days or inpatient mortality based on bundle compliance was shown.

That compliance with the overall bundle was only $49 \%$ is somewhat disappointing. We were unable to identify any other study reporting compliance with the complete COPD-X guideline [1] (or similar) bundle of care in ED so are unable to compare this figure with other hospitals/ countries. Deficits are shared fairly evenly across administration of systemic corticosteroids, administration of antibiotics if there was evidence of infection and analysis of blood gases in the case of non-mild disease, with a smaller contribution of the non-use of NIV in patients with respiratory acidosis. While lack of knowledge may be a contributor, it is more likely that the major reasons for missing bundle elements are human error with underlying reasons such a time contraints in ED, distraction and competing patient priorities as several patients are being processed by a doctor at any given time, imperfect memory and cognitive overload. One approach suggested to address deficits in care provided includes the introduction of a COPD proforma or checklist. Using this approach, Sen et al demonstrated improvements in categorization of respiratory failure, administration of controlled oxygen therapy and appropriate referral for NIV.[6] They did not examine other pharmacological elements of care. Similarly, McCarthy et al showed that a proforma improved compliance with defined treatments.[7] This approach may be effective because it makes doctors aware of, or reminds them about, 
guideline-based care. An alternative approach to improving compliance would be the use of a clinical informatics approach such as computer-assisted decision support which has been proven to improve patient safety and has been recommended by the US Agency for Healthcare Research and Quality.[8] This can range from simple reminder systems to monitor-based colour-coded bundle compliance visual alerts to computerized ventilator management[10] and is already being ised in a range of conditions in ED and ICU.

There is limited previously published data on guideline compliance for ED treatment of COPD in Australia. Considine at al [9] in a study of ED care for COPD in 5 hospitals in 2006-7 reported that inhaled bronchodilators were administered in $71 \%$ of patients, systemic corticosteroids in $56 \%$ and NIV in $50 \%$ of patients with respiratory acidosis (defined as $\mathrm{pH}<7.35$ ). They did not collect data on antibiotic or oxygen administration or taking of CXR or blood gases. They also only looked at items individually rather than as a bundle. Pleasingly, our results show significant improvement ( $86 \%$ vs $71 \%$ for inhaled bronchodilators, $79 \%$ vs $56 \%$ for systemic corticosteroids and $74 \%$ vs $50 \%$ for use of NIV in respiratory acidosis). A North American study [10] (19992001) reported a CXR rate of $87 \%$, blood gas analysis in $48 \%$ of patients, inhaled beta-agonists in $91 \%$, systemic corticosteroids in $62 \%$ and antibiotics in $28 \%$ of patients. Again, our results compare favorably. Reasons for this improvement might include better awareness of evidencebased therapies/ guidelines and changes to ambulance treatment protocols allowing bronchodilators and corticosteroids to be administered pre-hospital.

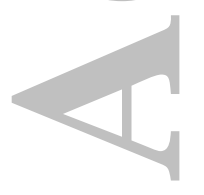

Rates of controlled oxygen use in our study were high. This is probably due to a sustained nursing education campaign over several years that has seen incremental improvements in the appropriate use of oxygen therapy in patients with COPD. A high proportion of patients were classified as requiring antibiotics according to the criteria applied in this study. While compliant 
with the spirit of the guideline, the clinical criterion of increased or purulent sputum and the investigation criteria of $\mathrm{WCC}>12$ and $\mathrm{CRP}>10$ may have over-called potential bacterial infection as viral infection can also result in these features. This is an area of ongoing controversy.

It is not surprising that compliance with an ED bundle for COPD did not impact mortality or LOS. The in-hospital mortality rate in our study was at the lower end of rates reported in the literature which range from $2 \%$ to $7.7 \%$ (median approx. $5 \%$ ).[11-17] Our study was not powered for this endpoint. Length of stay was similar to other contemporary reports.[13-14] ED care is only a small part of the treatment. Length of stay in particular is more likely to be impacted by treatment on the wards and co-morbidities than by ED care.

This study has some limitations that should be considered when interpreting its results. Data collection was retrospective with potential issues of missing data.[18] Sampling was not consecutive and therefore there is potential for selection bias, however we believe this is unlikely. This is a single site study (two hospitals within one health service) and may not be generalizable to other sites or health systems. We did not confirm diagnosis or severity using spirometry. This was not available in the participating ED and is rarely used in acute ED practice. The age cut-off of 40 years or older was arbitrarily chosen. It may have screened out some patienst with true COPD but the number is likely to be small. We are unable to report arterial $\mathrm{pCO}_{2}$ distribution and its relationship to treatment as the participating ED routinely use venous blood gas analysis to guide initial care. Given that severity assessment in the ED environment integrates clinical assessment (ability to speak, pulse rate, work of breathing, etc), investigation findings such as CXR and blood gas analysis and that venous blood gas analysis has been shown to have excellent agreement for $\mathrm{pH}$ [4] and to be an accurate screening tool for arterial hypercarbia [19], we do not consider the lack of an arterial pCO2 to have a major impact on our findings. We did not collect reasons why specific treatments or assessments were 
not used. There may have been legitimate reasons for their omission so our data may be an under-estimate of compliance with the management bundle.

\section{CONCLUSION}

Compliance with individual assessment and treatment recommendations was generally high, however compliance with the overall recommended bundle was only $50 \%$. This indicates that there is an opportunity to improve care in these patients. No difference in LOS, re-admission within 30 days or inpatient mortality based on bundle compliance was shown.

\section{FUNDING}

This project was supported by departmental funds only.

\section{COMPETING INTERESTS}

None to declare

\section{REFERENCES}

1. Abramson M et al. The COPDX Plan: Australian and New Zealand Guidelines for the management of Chronic Obstructive Pulmonary Disease 2014. http://www.copdx.org.au/ (Accessed February 2015)

2. Institute for Healthcare Improvement. Evidence-based care bundles. http://www.ihi.org/topics/bundles/Pages/default.aspx. Accessed December 2015.

3. Resar R, Pronovost P, Haraden C, Simmonds T, et al. Using a bundle approach to improve ventilator care processes and reduce ventilator-associated pneumonia. Joint Commission Journal on Quality and Patient Safety. 2005;31:243-248.

4. Kelly AM. Can venous blood gas analysis replace arterial in emergency medical care: A Review. Emerg Med Australas 2010; 22:493-8. 
5. Ruparel M, López-Campos JL, Castro-Acosta A, Hart S, Pozo-Rodriguez F, Roberts CM et al. Understanding variation in length of hospital stay for COPD exacerbation: European COPD audit. ERJ Open Res 2016; 2: 00034-2015.

6. Sen B, Woollard M, Desira NL. Does the Introduction of a COPD Pro-Forma Improve the Standards of Care Delivered by Junior Doctors in the Emergency Department. COPD: Journal of Chronic Obstructive Pulmonary Disease 2010; 7:3, 199-203.

7. McCarthy C, Brennan JR, Brown L, Donaghy D, Jones P, Whelan R et al. Use of a care bundle in the emergency department for acute exacerbations of chronic obstructive pulmonary disease: a feasibility study. Int J COPD 2013:8 605-611.

8. Ortiz E, Meyer G, Burstin H. Clinical Informatics and Patient Safety at the Agency for Healthcare Research and Quality. J Am Med Inform Assoc 2002; 9(6 Suppl 1): s2-s7.

9. Considine J, Botti M, Thomas S. Emergency department management of exacerbation of chronic obstructive pulmonary disease: audit of compliance with evidence-based guidelines. Intern Med J. 2011; 41:48-5.

10. Cydulka RK, Rowe BH, Clark S, Emerman CL, Camargo CA Jr, MARC investigators. Emergency department management of acute exacerbations of chronic obstructive pulmonary disease in the elderly: the Multicenter Airway Research Collaboration. J Am Geriatr Soc 2003;51:908-1.

11. Kelly AM, Klim S. Is elevated troponin associated with in-hospital mortality in emergency department patients admitted with chronic obstructive pulmonary disease? Eur J Emerg Med $2013 ; 20: 54-7$. 
12. Tsai CL, Delclos CL, Camargo CA Jnr. Emergency department case volume and patient outcomes in acute exacerbations of chronic obstructive pulmonary disease. Acad Emerg Med $2012 ; 19: 656-63$.

13. Johannesdottir SA, Christiansen CF, Johansen MB, Olsen M, Xu X, Parker JM et al. Hospitalization with acute exacerbation of chronic obstructive pulmonary disease and associated health resource utilization: a population-based Danish cohort study.

J Med Econ 2013;16:297-906.

14. George PM, Stone RA, Buckingham RJ, Pursey NA, Lowe D, Roberts CM. Changes in NHS organization of care and management of hospital admissions with COPD exacerbations between the national COPD audits of 2003 and 2008. QJM 2011;104:859-66.

15. Perera PN, Armstrong EP, Sherrill DL, Skrepnek CH. Acute exacerbations of COPD in the United States: inpatient burden and predictors of costs and mortality. COPD 2012; 9:131-41.

16. Dransfield MT, Rowe SM, Johnson JE, Bailey WC, Gerald LB. Use of beta blockers and the risk of death in hospitalised patients with acute exacerbations of COPD. Thorax 2008;63:301-5. 17. Roche N Zureik M, Soussan D, Neukirch F, Perrotin D, Urgence BPCO (COPD Emergency Scientific Committee). Predictors of outcomes in COPD exacerbation cases presenting to the emergency department. Eur Resp J 2008;32:953-61.

18. Gilbert EH, Lowenstein SR, Kosiol-McLain J, Barta DC, Steiner J. Chart reviews in emergency medicine research: Where are the methods? Ann Emerg Med 1996; 27:305-8.

19. Kelly A-M. Can VBG analysis replace ABG analysis in emergency care? Emerg Med J 2016;33:152-154. 
Table 1. Characteristics of the sample

\begin{tabular}{|c|c|c|}
\hline Characteristic & Result & Missing data \\
\hline Age (years, mean, SD) & $71(12)$ & 0 \\
\hline Gender (male, N, \%, 95\% Cl) & $227,60 \%(55-64 \%)$ & 0 \\
\hline \multicolumn{3}{|l|}{ Co-morbidities } \\
\hline Heart failure $(\mathrm{N}, \%,, 95 \% \mathrm{Cl})$ & $103,27 \%(23-32 \%)$ & 0 \\
\hline Diabetes $(\mathrm{N}, \%, 95 \% \mathrm{Cl})$ & $101,27 \%(22-31 \%)$ & 0 \\
\hline chaemic heart disease $(\mathrm{N}, \%, 95 \% \mathrm{Cl})$ & $108,28 \%(24-33 \%)$ & 0 \\
\hline Smoker (N, \%, 95\% Cl) & $142,37 \%(33-42 \%)$ & 0 \\
\hline \multicolumn{3}{|l|}{ Chronic medications } \\
\hline Inhaled beta-sympathomimetics $(\mathrm{N}, \%, 95 \% \mathrm{Cl})$ & $329,86 \%(83-89 \%)$ & 0 \\
\hline Inhaled anti-cholinergics ( $\mathrm{N}, \%, 95 \% \mathrm{Cl})$ & $272,71 \%(67-78 \%)$ & 0 \\
\hline haled corticosteroids ( $\mathrm{N}, \%, 95 \% \mathrm{Cl})$ & $250,66 \%(61-70 \% 0$ & 0 \\
\hline Oral corticosteroids $(\mathrm{N}, \%, 95 \% \mathrm{Cl})$ & $97,25 \%(21-30 \%)$ & 0 \\
\hline Antibiotics (N, \%, 95\% Cl) & $58,15 \%(12-19 \%)$ & 0 \\
\hline Home oxygen $(\mathrm{N}, \%, 95 \% \mathrm{Cl})$ & $71,19 \%(15-23 \%)$ & 0 \\
\hline Diuretic $(\mathrm{N}, \%, 95 \% \mathrm{Cl})$ & $151,40 \%, 35-45 \%)$ & 0 \\
\hline Xanthine $(\mathrm{N}, \%, 95 \% \mathrm{Cl})$ & $3,0.8 \%(0.3-2.3 \%)$ & 0 \\
\hline Mode of arrival (ambulance, $\mathrm{N}, \%, 95 \% \mathrm{Cl}$ ) & $294,78 \%, 74-82 \%)$ & 5 \\
\hline Duration of symptoms (median, IQR) & $3,2-6$ & 23 \\
\hline Severity of exacerbation & & 49 \\
\hline Mild (N, \%, 95\% Cl) & $103,31 \%(26-36 \%)$ & \\
\hline Moderate $(\mathrm{N}, \%, 95 \% \mathrm{Cl})$ & $181,55 \%(49-60 \%)$ & \\
\hline Severe $(\mathrm{N}, \%, 95 \% \mathrm{Cl})$ & $48,14 \%(11-19 \%)$ & \\
\hline Clinical features & & \\
\hline Respiratory rate $\geq 30(\mathrm{~N}, \%, 95 \% \mathrm{Cl})$ & $89,23 \%(19-28 \%)$ & 2 \\
\hline
\end{tabular}




\begin{tabular}{|c|c|c|}
\hline Blood pressure $<100(\mathrm{~N}, \%, 95 \% \mathrm{Cl})$ & $26,7 \%(5-10 \%)$ & 1 \\
\hline Temperature $\geq 38.5 \mathrm{C}(\mathrm{N}, \%, 95 \% \mathrm{Cl})$ & $33,9 \%(6-12 \%)$ & 9 \\
\hline Pulse rate $\geq 120(\mathrm{~N}, \%, 95 \% \mathrm{Cl})$ & $65,17 \%(14-21 \%)$ & 1 \\
\hline $\begin{array}{r}\text { Oxygen saturation on air }<88 \%(\mathrm{~N}, \%, 95 \% \mathrm{Cl}) \\
{ }^{*} \text { Note: all other patients were on supplemental } \\
\text { oxygen at initial assessment }\end{array}$ & $104,37 \%(31-42 \%)$ & $97^{*}$ \\
\hline Clinical evidence of infection $(\mathrm{N}, \%, 95 \% \mathrm{Cl})$ & $160,42 \%(37-47 \%)$ & 0 \\
\hline \multicolumn{3}{|l|}{ Investigations } \\
\hline White cell count $>12(\mathrm{~N}, \%, 95 \% \mathrm{Cl})$ & $131,35 \%(31-40 \%)$ & 10 \\
\hline $\mathrm{pH}<7.3$ (arterial or venous, $\mathrm{N}, \%, 95 \% \mathrm{Cl}$ ) & $40,16 \%(12-21 \%)$ & $\begin{array}{l}128 \text { - blood gas not } \\
\text { performed }\end{array}$ \\
\hline CXR performed $(\mathrm{N}, \% ; 95 \% \mathrm{Cl})$ & $373,98 \%(96-99 \%)$ & 0 \\
\hline Infiltrate on CXR (N, \%; 95\% Cl) & $133,36 \%(31-41 \%)$ & 0 \\
\hline
\end{tabular}


Table 2. Treatment and outcome in ED

\begin{tabular}{|c|c|}
\hline Treatment & Result \\
\hline $\begin{array}{l}\text { Controlled oxygen therapy after initial nurse assessment, if oxygen } \\
\text { administered }(\mathrm{N} / \text { denominator, } \%, 95 \% \mathrm{Cl})\end{array}$ & $265 / 294,90 \%(86-93 \%)$ \\
\hline $\begin{array}{l}\text { Inhaled bronchodilator (beta sympathomimetic, anti-cholinergic or both; } \mathrm{N} \text {, } \\
\% ; 95 \% \mathrm{Cl} \text { ) }\end{array}$ & $332,87 \%(83-90 \%)$ \\
\hline Systemic corticosteroid (oral or IV; $\mathrm{N}, \% ; 95 \% \mathrm{Cl}$ ) & $301,79 \%(75-83 \%)$ \\
\hline $\begin{array}{l}\text { Antibiotics if evidence of infection (purulent sputum, fever }>38, \text { raised } \\
W C C \geq 12 \text { or } C R P \geq 10, C X R \text { shows infection) (N/denominator, } \%, 95 \% \\
\mathrm{Cl})\end{array}$ & $217 / 289,75 \%(70-80 \%)$ \\
\hline $\begin{array}{l}\text { Blood gas if moderate or severe illness or oxygen saturation }<90 \%(\mathrm{~N} / \\
\text { denominator, } \% ; 95 \% \mathrm{Cl} \text { ) }\end{array}$ & $219 / 271,81 \%(76-85 \%)$ \\
\hline CXR taken (N, \%; 95\% Cl) & $373,98 \%(96-99 \%)$ \\
\hline NIV if $\mathrm{pH}<7.3$ (N/denominator, \%; 95\% Cl) & $29 / 40,73 \%(57-84 \%)$ \\
\hline Compliance with all applicable bundle elements (N, \%; 95\% Cl) & $186,49 \%(44-54 \%)$ \\
\hline \multicolumn{2}{|l|}{ Outcome } \\
\hline Admitted to hospital ward (N, \%; 95\% Cl) & $288,76 \%(71-80 \%)$ \\
\hline $\begin{array}{l}\text { Length of stay -median, days, IQR (admitted patients; } \mathrm{N}=287 \text { ) } \\
\text { Note: } 1 \text { inter-hospital transfer with incomplete data }\end{array}$ & $5,4-8$ \\
\hline In-hospital mortality - admitted patients (N/denominator, \%; 95\% Cl) & $11 / 287,3.8 \%(2.2-6.7 \%)$ \\
\hline \multicolumn{2}{|l|}{$\begin{array}{l}\text { Re-admission to hospital ward within } 30 \text { days (N, \%; denominator; } 95 \% \\
\mathrm{Cl} \text { ) }\end{array}$} \\
\hline $\begin{array}{l}\text { Patients admitted to ward at index visit } \\
{ }^{*} \text { There were } 11 \text { in-hospitals deaths }\end{array}$ & $73 / 278^{*}, 26 \%(21-32 \%)$ \\
\hline Patients discharged from ED at index visit & $24 / 92,26 \%(18-36 \%)$ \\
\hline
\end{tabular}

This article is protected by copyright. All rights reserved. 


\section{COPD BUNDLE CASE REPORT FORM}

1. CASE NUMBER \& DEMOGRAPHICS

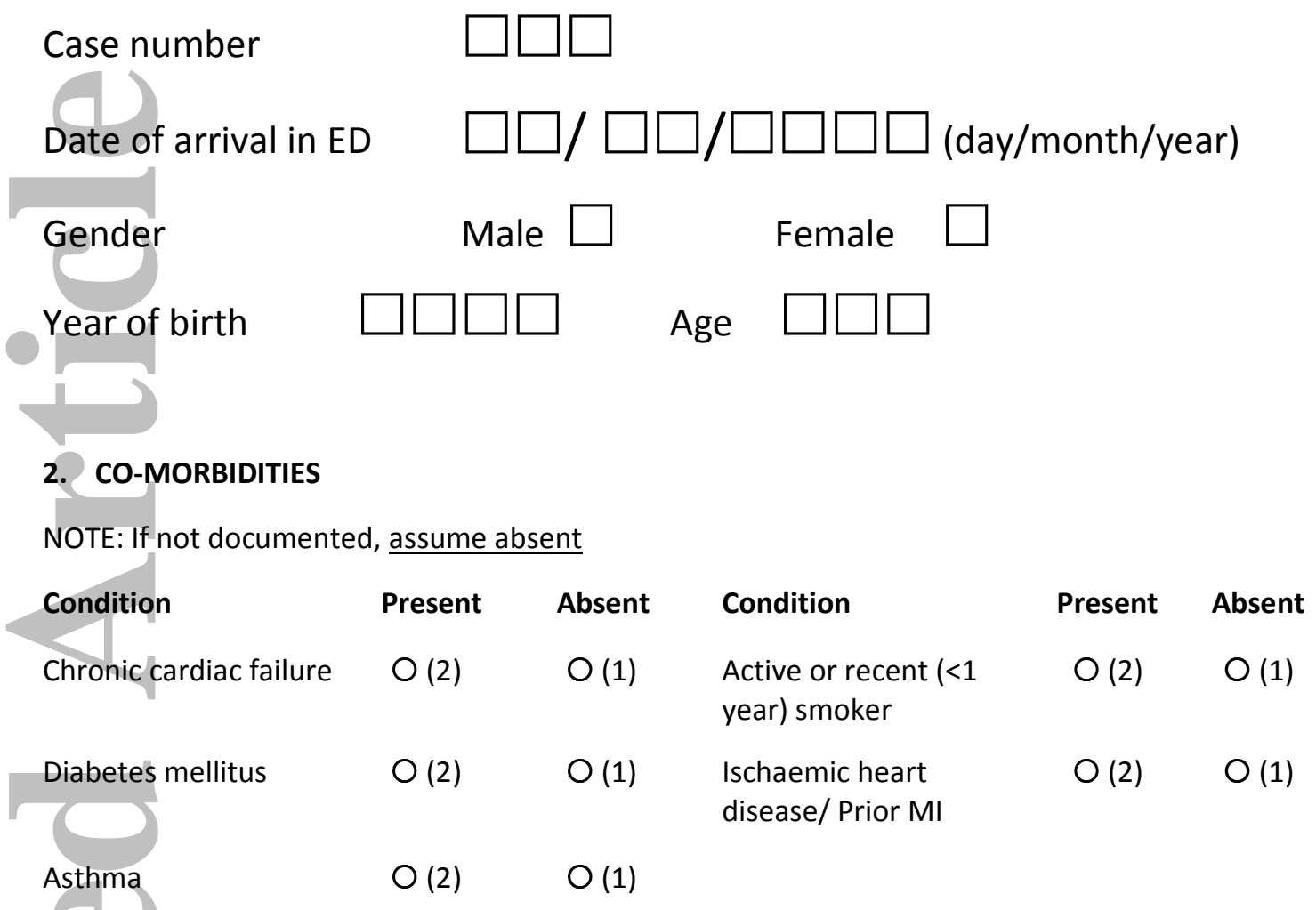

3. USUAL MEDICATION (CHRONIC USE)

NOTE: If not documented, assume absent

\begin{tabular}{|c|c|c|c|c|c|}
\hline Name/Class & No & Yes & Name/ Class & No & Yes \\
\hline $\begin{array}{l}\text { Inhaled beta- } \\
\text { sympathomimetics e.g. } \\
\text { salbutamol, salmeterol (alone } \\
\text { or in combination) }\end{array}$ & $\bigcirc(1)$ & $\bigcirc(2)$ & Home oxygen & $O(1)$ & $\bigcirc(2)$ \\
\hline Inhaled anti-cholinergic agent & $\bigcirc(1)$ & $\bigcirc(2)$ & Diuretic & $O(1)$ & $O(2)$ \\
\hline $\begin{array}{l}\text { Inhaled corticosteroid (alone } \\
\text { or in combination) }\end{array}$ & $\bigcirc(1)$ & $\bigcirc(2)$ & $\begin{array}{l}\text { Leukotriene receptor } \\
\text { antagonist }\end{array}$ & $O(1)$ & $O(2)$ \\
\hline Oral corticosteroid & $O(1)$ & $O(2)$ & $\begin{array}{l}\text { Xanthine e.g. } \\
\text { Theophylline }\end{array}$ & $O(1)$ & $O(2)$ \\
\hline Antibiotic & $\bigcirc(1)$ & $O(2)$ & & & \\
\hline
\end{tabular}

\section{MODE OF ARRIVAL}

Self, private car - go to question 6 


\section{COPD BUNDLE CASE REPORT FORM}

5. PRE-HOSPITAL TREATMENT BY AMBULANCE (leave blank if did not come by ambulance)

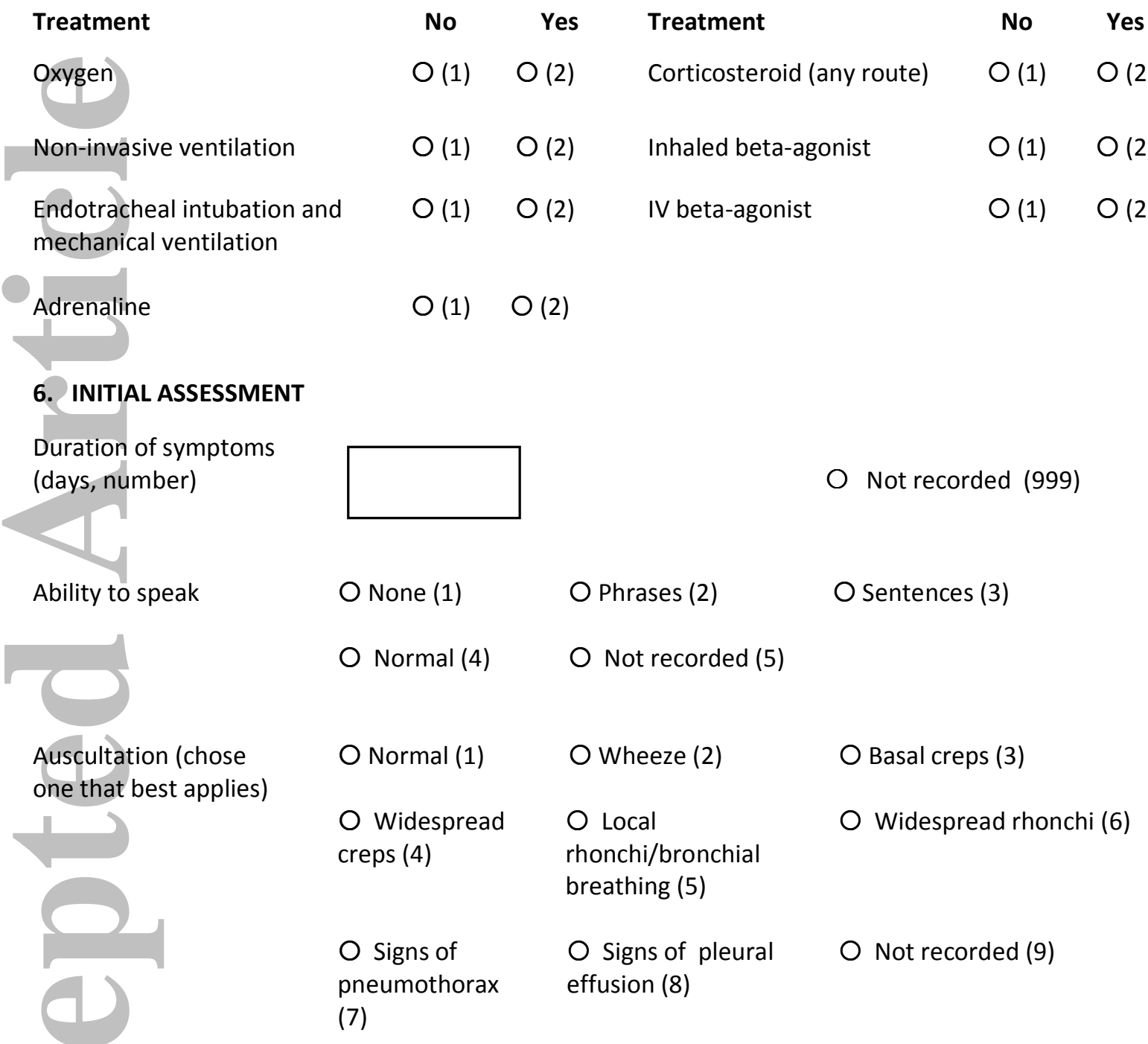

For the items below, use worst value in the first hour of ED care

Respiratory rate

(number)

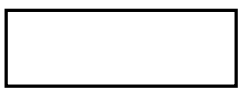

Not recorded (999)

Systolic BP (number)

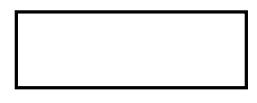

Not recorded (999)

Temperature (number)

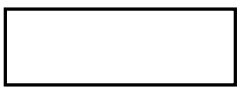

Not recorded (999)

Pulse rate (number)

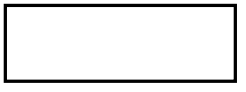

O Not recorded (999)

Oxygen saturation on air, if known (number)

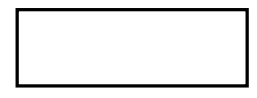

Not recorded (999)

Oxygen saturation on oxygen (number)

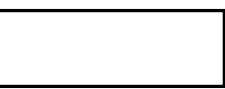

Not recorded (999) 


\section{COPD BUNDLE CASE REPORT FORM}

Clinical evidence of infection (purulent sputum, fever) $\mathrm{O}$ No (1) $\quad$ Yes (2) Severity assessment -
recorded or implied $\quad$ Mild (1) O Moderate (2) O Severe (3) $\quad$ O Not recorded (4)

\section{INVESTIGATIONS (leave blank if not taken)}

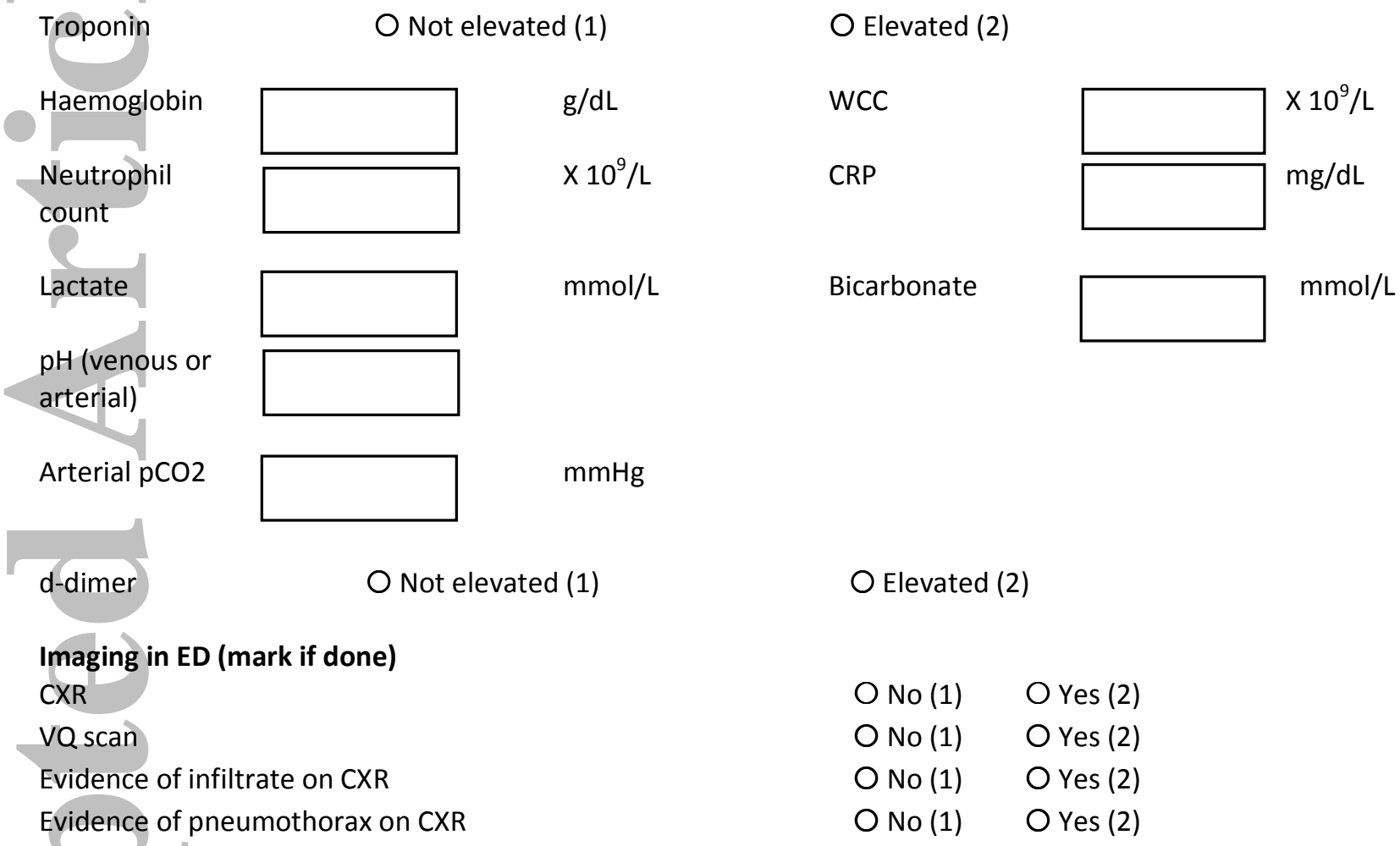

\section{TREATMENT IN THE EMERGENCY DEPARTMENT}

$\begin{array}{lllll}\begin{array}{l}\text { INITIAL Oxygen } \\ \text { delivery system in ED }\end{array} & \text { O None (1) } & \begin{array}{l}\text { O Standard Face } \\ \text { mask e.g. Hudson } \\ \text { mask (2) }\end{array} & \begin{array}{l}\text { O venturi system } \\ (3)\end{array} & \begin{array}{l}\text { O Non-rebreather } \\ \text { mask (4) }\end{array} \\ & \begin{array}{l}\text { O Low flow nasal } \\ \text { prongs (5) }\end{array} & \begin{array}{l}\text { O Humidified high } \\ \text { flow nasal O2 (6) }\end{array} & \text { O CPAP (7) } & \text { O BiPAP (8) } \\ & \text { O Bag valve mask (9) } & \begin{array}{l}\text { O Mechanical } \\ \text { ventilation (10) }\end{array} & \begin{array}{l}\text { O Oxygen given but } \\ \text { mode unknown (11) }\end{array} & \\ \begin{array}{l}\text { Oxygen delivery } \\ \text { systems in ED (tick all } \\ \text { that apply) }\end{array} & \text { O None (1) } & \begin{array}{l}\text { O Standard Face } \\ \text { mask e.g. Hudson } \\ \text { mask (2) }\end{array} & \begin{array}{l}\text { O Venturi system } \\ \text { (3) }\end{array} & \begin{array}{l}\text { O Non-rebreather } \\ \text { mask (4) }\end{array} \\ & \begin{array}{l}\text { O Low flow nasal } \\ \text { prongs (5) }\end{array} & \begin{array}{l}\text { O Humidified high } \\ \text { flow nasal O2 (6) }\end{array} & \text { O CPAP (7) } & \text { O BiPAP (8) } \\ & \text { O Bag valve mask (9) } & \begin{array}{l}\text { O Mechanical } \\ \text { ventilation (10) }\end{array} & \begin{array}{l}\text { O Oxygen given but } \\ \text { mode unknown (11) }\end{array}\end{array}$




\section{COPD BUNDLE CASE REPORT FORM}

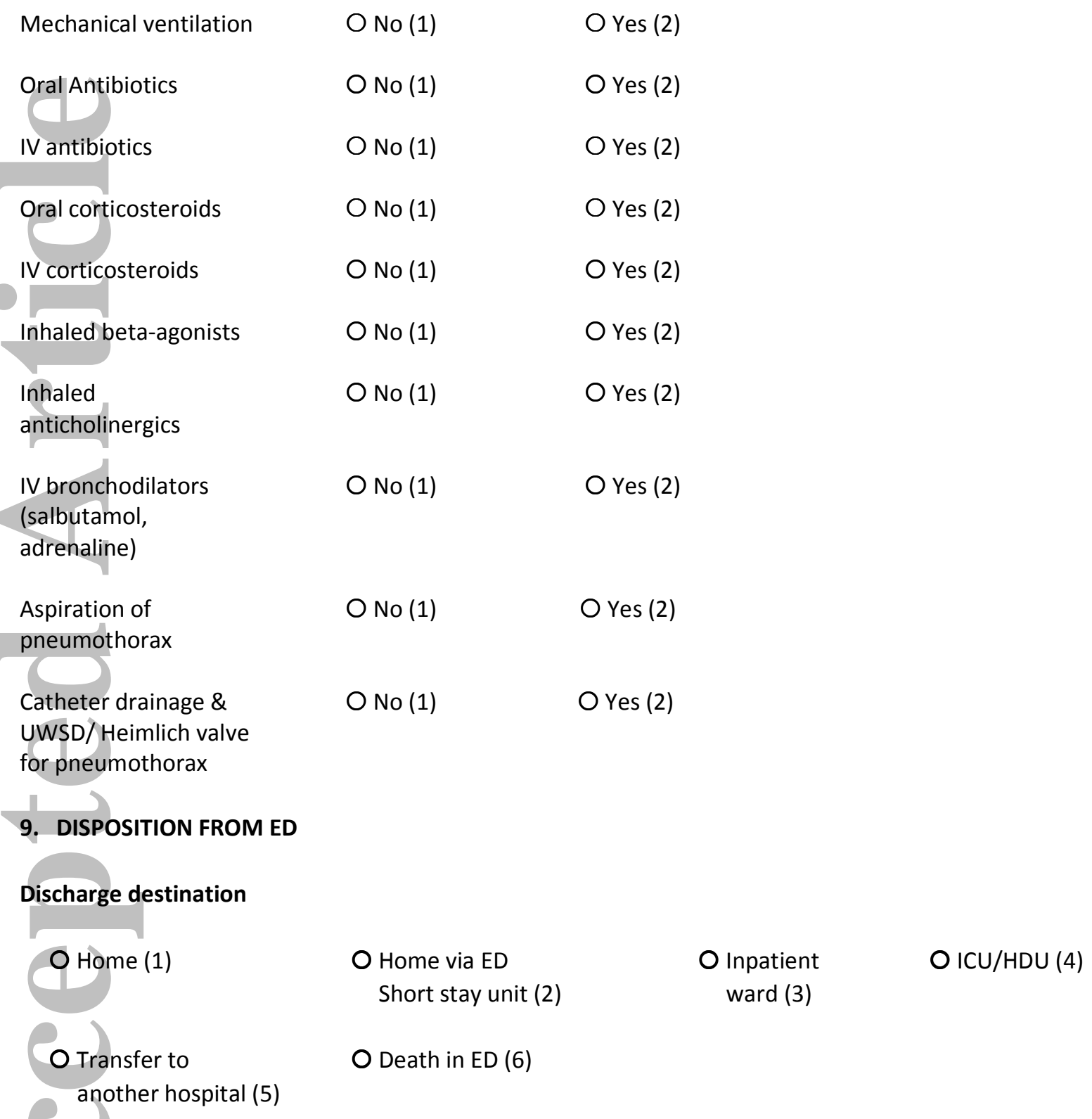

10. IF ADMITTED, FINAL HOSPITAL DISCHARGE

Date of hospital discharge (day/month/ year)

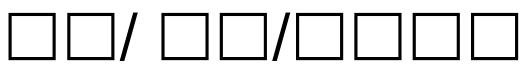

Y Yes (2) O No (1)

O No (1) O Yes (2)
Re-admit within 30 days

Discharged alive
Total LOS (include day of arrival at ED and day of discharge; days) 


\section{COPD BUNDLE CASE REPORT FORM}

ADMIN USE ONLY (AMK to complete):

\section{COMPLIANCE WITH BUNDLE OF CARE ELEMENTS}

\begin{tabular}{|l|l|l|}
\hline COMPONENT & COMPLETED & $\begin{array}{l}\text { NOT } \\
\text { APPLICABLE }\end{array}$ \\
\hline $\begin{array}{l}\text { Controlled oxygen therapy after initial nurse contact (prongs, } \\
\text { venturi, CPAP) }\end{array}$ & & \\
\hline Inhaled bronchodilators (salbutamol, ipratropium, both) & & \\
\hline Corticosteroids & & \\
\hline Antibiotics if evidence of infection (purulent sputum, fever > & & \\
38, raised WCC or CRP, CXR shows infection) & & \\
\hline CXR taken & & \\
\hline Blood gas if severity moderate, severe or SpO2 $<90$ & & \\
\hline NIV if pH $<7.3$ & & \\
\hline
\end{tabular}

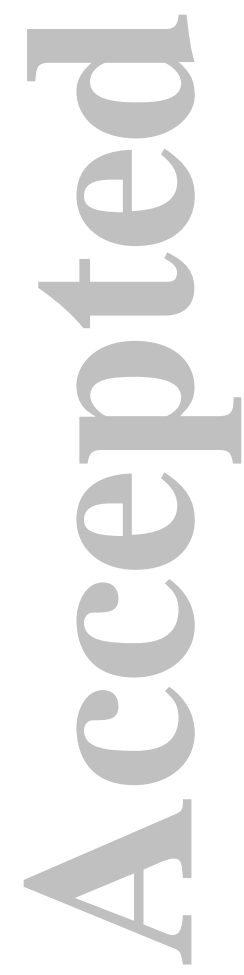




\section{University Library}

\section{- M M N E R VA A gateway to Melbourne's research publications}

Minerva Access is the Institutional Repository of The University of Melbourne

Author/s:

Gerber, A;Moynihan, C;Klim, S;Ritchie, P;Kelly, A-M

Title:

Compliance with a COPD bundle of care in an Australian emergency department: A cohort study

Date:

2018-02-01

Citation:

Gerber, A., Moynihan, C., Klim, S., Ritchie, P. \& Kelly, A. -M. (2018). Compliance with a COPD bundle of care in an Australian emergency department: A cohort study. CLINICAL RESPIRATORY JOURNAL, 12 (2), pp.706-711. https://doi.org/10.1111/crj.12583.

Persistent Link:

http://hdl.handle.net/11343/292218 